\title{
HOW CAN INFRINGEMENTS OF THE CONSTITUTIONAL RIGHTS OF ABoriginal Peoples Be Justified?
}

\section{Kent McNeil}

On August 21, 1996, the Supreme Court of Canada handed down three decisions on Aboriginal fishing rights in British Columbia: $R$. v. Van der Peet, ${ }^{1}$ R. v. N.T.C. Smokehouse, ${ }^{2}$ and R. v. Gladstone. ${ }^{3}$ These decisions, already known as the Van der Peet trilogy, were followed by a decision on Aboriginal selfgovernment in relation to high-stakes gambling in Ontario, $R$. v. Pamajewon, ${ }^{4}$ released the next day. Then on October 3, 1996, the Court handed down two more decisions, this time involving Aboriginal fishing rights in Quebec: R. v. Adams ${ }^{5}$ and $R$. v. Coté ${ }^{6}$ All these decisions deal with section $35(1)$ of the Constitution Act, $1982,{ }^{7}$ and the nature of the Aboriginal rights which that section recognizes and affirms. Together, these six decisions are probably the most important pronouncements on Aboriginal rights the Supreme Court has made so far. They are going to have a profound impact on the Aboriginal peoples, and will influence not only future judicial decisions but negotiations for the resolution of Aboriginal claims as well.

While these decisions raise a variety of vital issues in relation to Aboriginal rights and section 35(1), my commentary will focus on the test the Supreme Court used for justification of federal legislative infringements of these rights. The Supreme Court created that test in R. v. Sparrow, ${ }^{8}$ and it has now been elaborated in Gladstone, in particular.

S.C.C. No. 23803, [1996] S.C.J. No. 77.

S.C.C. No. 23800, [1996] S.C.J. No. 78.

S.C.C. No. 23801, [1996] S.C.J. No. 79.

S.C.C. No. 24596, [1996] S.C.J. No. 20.

S.C.C. No. 23615 , [1996] S.C.J. No. 87.

S.C.C. No. 23707, [1996] S.C.J. No. 93.

Schedule B of the Canada Act 1982 (U.K.), 1982, c.11.

Section 35(1) provides: "The existing aboriginal and treaty rights of the aboriginal peoples of Canada are hereby recognized and affirmed."

[1990] 1 S.C.R. 1075.
The Sparrow test for justification places a twopart burden of proof on the Crown. Once an infringement of an existing Aboriginal right has been shown, the Crown has to prove, first, that there was a "valid legislative objective" for the infringement. ${ }^{9}$ The Court explained: ${ }^{10}$

An objective aimed at preserving section 35 (1) rights by conserving and managing a natural resource, for example, would be valid. Also valid would be objectives purporting to prevent the exercise of section 35 (1) rights that would cause harm to the general populace or to aboriginal peoples themselves, or other objectives found to be compelling and substantial.

The Court decided that conservation and management of fish stocks were sufficiently compelling and substantial legislative objectives to justify infringement of constitutionally-protected Aboriginal fishing rights if that was necessary to preserve the resource. Infringement of those rights could not, however, be justified on the basis of the "public interest." The Court found "the 'public interest' justification to be so vague as to provide no meaningful guidance and so broad as to be unworkable as a test for the justification of a limitation on constitutional rights." "Nor would it be sufficient for the Crown to prove that its objective was "reasonable." According to the Court, "the fact that the objective is of a 'reasonable' nature cannot suffice as 
constitutional recognition and affirmation of aboriginal rights."12

If the Crown is able to point to a valid legislative objective, the analysis moves to the second part of the justification test which requires the Crown to prove that the measures taken to meet that objective are consistent with its fiduciary duty towards the Aboriginal peoples. In the Court's words, the "special trust relationship and the responsibility of the government vis-à-vis aboriginals must be the first consideration in determining whether the legislation or action in question can be justified." "Fulfillment of the fiduciary duty in this context requires that certain considerations be taken into account. Specifically, the Court said that " $t \mathrm{t}]$ hese include the questions of whether there has been as little infringement as possible in order to effect the desired result; whether, in a situation of expropriation, fair compensation is available; and, whether the aboriginal group in question has been consulted with respect to the conservation measures being implemented." 14 More concretely, where utilization of a resource must be limited to meet the valid objective of conservation, the impact of the conservation measures must limit non-Aboriginal use of the resource first. The reason for this is that Aboriginal rights to the resource are constitutionally protected, and therefore must be given priority over the rights of other users which are not constitutionally protected. The Court put it this way: ${ }^{15}$

The constitutional nature of the Musqueam food fishing rights means that any allocation of priorities after valid conservation measures have been implemented must give top priority to Indian food fishing.... If, in a given year, conservation needs required a reduction in the number of fish to be caught such that the number equalled the number required for food by the Indians, then all the fish available after conservation would go to the Indians according to the constitutional nature of their fishing right. If, more realistically, there were still fish left after the

12 Ibid. at 1118. Compare R. v. Badger (1996), 195 N.R. I (S.C.C.) esp. 38; R. v. Nikal (1996), 196 N.R. I (S.C.C.), at 61-7.

$13 \quad R$. v. Sparrow, supra note 8 at 1114 . As an aside, I have never understood how the Crown can justify its own infringements of the rights of the Aboriginal peoples when, as a fiduciary, it is duty-bound to uphold and protect those rights. For me, this is a central contradiction of the whole justification test

$14 \quad$ Ibid at 1119

is Ibid. at 1116 .
Indian food requirements were met, then the brunt of conservation measures would be borne by the practices of sport fishing and commercial fishing.

The reason the priority was limited to the Musqueam food fishery was that the Aboriginal right relied on in Sparrow was limited to a right to fish for food, which was taken to include fishing for social and ceremonial purposes. For the Crown's fiduciary duty to be met in a way that respects the constitutional recognition and affirmation of this right, the food fishery had to be given top priority. Any limitation, even for the valid legislative objective of conservation, that did not give the right priority could not be justified, and therefore would be unconstitutional.

The issue of justification arose in the Gladstone decision. In Gladstone the appellants, who are members of the Heiltsuk Band in British Columbia, were able to prove to the satisfaction of the majority of the Court that they have an existing Aboriginal right to sell herring spawn on kelp commercially, and that the right had been infringed by federal fishery regulations made pursuant to the Fisheries Act. ${ }^{16}$ The next question for the majority was whether the infringement could be justified on the basis of the Sparrow test for justification. On this question, the majority took an approach that, in my view, is significantly different from the approach taken in Sparrow.

As we have seen, the first part of the justification test requires proof by the Crown of a valid legislative objective. While the validity of the legislative objective of conservation was described by the Court in Sparrow as "uncontroversial,"17 the regulations being challenged in Gladstone went beyond conservation." The regulatory scheme involved initial determinations of how much herring stock could be harvested in a given year and how that stock was to be allocated to the different herring fisheries (of which herring spawn on kelp was one), but it also involved allocation of the resource among various user groups. As allocation among the user groups has little or nothing to do with conservation, Chief Justice Lamer, in his majority judgment, found it necessary "to consider what, if any,

16 R.S.C. 1970 , c. F-14, now R.S.C. 1985 , c. F-14. Note that La Forest J. dissented on the issues of the nature of the Aboriginal right and whether it had been extinguished. L'Heureux-Dubé J. took a different position from the majority on the test for establishing an Aboriginal right, and McLachlin J. took a different position on the infringement issue.

7 R. v. Sparrow, supra note 8 at 1113 
objectives the government may pursue, other than conservation, which will be sufficient to satisfy the first branch of the Sparrow justification standard."18 Ultimately, Lamer C.J. was unable to determine whether the objectives behind the allocation were valid because no evidence regarding objectives had been led, so the case was sent back to trial to resolve that issue. He did, nonetheless, make some general observations on what kind of objectives might meet the test.

Chief Justice Lamer affirmed the Sparrow requirement that the objectives would have to be "compelling and substantial."19 $\mathrm{He}$ went on to say that the purposes underlying the recognition and affirmation of Aboriginal rights in section 35(1) "must inform not only the definition of the rights but also the identification of those limits on the rights which are justifiable." ${ }^{20}$ Those purposes were stated by Lamer C.J. in the Van der Peet decision as: ${ }^{21}$

... first, the means by which the constitution recognizes the fact that prior to the arrival of Europeans in North America the land was already occupied by distinctive aboriginal societies, and as, second, the means by which that prior occupation is reconciled with the assertion of Crown sovereignty over Canadian territory.

Applying this statement of the purposes of section 35(1) in Gladstone, Lamer C.J. said that: ${ }^{22}$

... the import of these purposes is that the objectives which can be said to be compelling and substantive will be those directed at either the recognition of the prior occupation of North America by aboriginal peoples or - and at the level of justification it is this purpose which may well be most relevant - at the reconciliation of aboriginal prior occupation with the assertion of sovereignty by the Crown.

One may wonder how any law infringing Aboriginal rights could ever have as its purpose "the recognition of the prior occupation of North America. by aboriginal peoples." Leaving that apparent contradiction aside we will focus, as did Lamer C.J., on

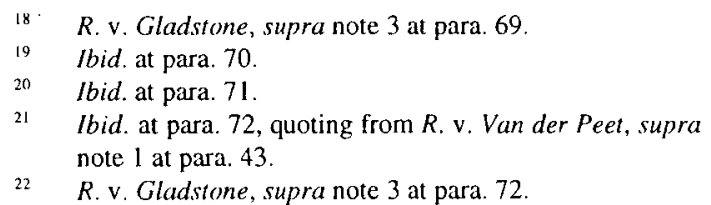

objectives aimed at reconciling that occupation with the Crown's sovereignty. In this context, he said: ${ }^{23}$

Because ... distinctive aboriginal societies exist within, and are a part of, a broader social, political and economic community, over which the Crown is sovereign, there are circumstances in which, in order to pursue objectives of compelling and substantial importance to that community as a whole (taking into account the fact that aboriginal societies are a part of that community), some limitation of those rights will be justifiable. Aboriginal rights are a necessary part of the reconciliation of aboriginal societies with the broader political community of which they are part; limits placed on those rights are, where the objectives furthered by those limits are of sufficient importance to the broader community as a whole, equally a necessary part of that reconciliation.

While it is clear from the Sparrow decision that Aboriginal rights are not absolute, ${ }^{24}$ the examples the Court gave there of compelling and substantial objectives which justify infringement of those rights involved objectives that either maintain the rights by conserving the resources on which the rights depend or ensure that the rights are not exercised in a dangerous way. Other compelling and substantial objectives might involve balancing the constitutional rights of the Aboriginal peoples against the constitutional rights of non-Aboriginal Canadians in circumstances of potential conflict. But Lamer C.J. went much further than that in Gladstone. For him, it appears that objectives of sufficient importance to Canadians generally can be compelling and substantial, even where no conflicting constitutional rights are involved. This looks very much like the "public interest" justification that the Court rejected in Sparrow.

More specifically, in the context of the Aboriginal fishing rights at issue in Gladstone, Lamer C.J. said this: $:^{25}$

$23 \quad$ Ibid. at para. 73

24 For a critical discussion of why the Court took that position in Sparrow, see K. McNeil, "Envisaging Constitutional Space for Aboriginal Governments" (1993) 19 Queen's L.J. 95.

$25 \quad R$. v.Gladstone, supra note 3 at para. 75 . Sce also $R$. v. Adamis, supra note 5, and $R$. v. Coté, supra note 6, where in each case the Crown failed to prove a valid legislative objective. 
Although by no means making a definitive statement on this issue, I would suggest that with regards to the distribution of the fisheries resource after conservation goals have been met; objectives such as the pursuit of economic and regional fairness, and the recognition of the historical reliance upon, and participation in, the fishery by nonaboriginal groups, are the type of objectives which can (at least in the right circumstances) satisfy this standard. In the right circumstances, such objectives are in the interest of all Canadians and, more importantly, the reconciliation of aboriginal societies with the rest of Canadian society may well depend on their successful attainment.

We need to be clear that what Lamer C.J. was referring to here was not reconciliation through agreements negotiated with Aboriginal peoples, but rather reconciliation through unilaterally imposed legislative infringements of their constitutional rights. ${ }^{26}$ This sounds less like an approach designed to achieve real reconciliation through mutual respect and negotiated settlements and more like a continuation of the historical treatment of the Aboriginal peoples, whereby, in the words of Dickson C.J. and La Forest $\mathbf{J}$. in Sparrow, their rights "were often honoured in the breach." ${ }^{27}$ While one can appreciate that the interests of non-Aboriginal groups in the fishery are also involved, the fact is that if those interests are in conflict with Aboriginal fishing rights today, then the historical reliance upon and participation in the fishery by those groups in the past was probably in violation of Aboriginal rights as well. Can reconciliation really be achieved by judicially-authorized perpetuation of past injustices rather than sitting down and working out mutually-acceptable solutions to these conflicts?

More broadly, in the passage quoted above Lamer C.J. suggested that "objectives such as the pursuit of economic and regional fairness" might, "in the right circumstances," satisfy the "compelling and substantial" standard laid down in Sparrow. Here Lamer C.J. was not concerned with conservation, or public safety, or conflicting constitutional or even legal rights - he was referring to economic interests. But of what value are

26 The Crown's fiduciary duty requires consultation with affected Aboriginal groups, but their agreement is not necessary for their rights to be infringed: see Sparrow, supra note 8 , esp. the passage at 1119 quoted supra in text accompanying note 14

$27 \quad R$. v. Sparrow, supra note 8 at 1103. the constitutional rights of the Aboriginal peoples if they can be over-ridden to meet economic considerations in the distribution of resources? Should economic and regional fairness serve to justify infringement of constitutional rights, especially the rights of the Aboriginal peoples which are not subject to section 1 of the Charter? $?^{28}$ And how can this be fair to Aboriginal peoples, when their lands have been taken from them and their economies and ways of life have been devastated by European colonization, with the result that they are at the bottom of the scale in Canada on virtually every economic and social indicator?

Justice McLachlin did point out some of the problems with Lamer C.J.'s approach to the justification issue. While she did not deal with this issue herself in Gladstone, ${ }^{29}$ she was very critical of Lamer C.J.'s approach in her dissenting judgment in Van der Peet. She thought his approach was inconsistent with earlier authorities, in particular the Sparrow decision, because his interpretation of the Sparrow test for justification extended the meaning of "compelling and substantial" purpose, in her words, "to any goal which can be justified for the good of the community as a whole, aboriginal and non-aboriginal." ${ }^{130}$ After citing the above-quoted passage from his judgment referring to economic and regional fairness, she said this: ${ }^{31}$

Leaving aside the undefined limit of "proper circumstances," the historical reliance of the participation of non-aboriginal fishers in the fishery seems quite different from the compelling and substantial objectives the Court described in Sparrow - conservation of the resource, prevention of harm to the population, or prevention of harm to the aboriginal people themselves. These are indeed compelling objectives, relating to the fundamental conditions of the responsible exercise of the right. As such, it may safely be said that right-thinking persons would agree that these limits may properly be applied to the exercise of even constitutionally entrenched rights.

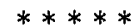

28 Aboriginal rights are not subject to section 1 because the section recognizing and affirming those rights, viz. s.35, is outside the Charter.

29 This was because her opinion on the nature of the Aboriginal right and whether it had been infringed or not made it unnecessary for her to consider justification.

$30 \quad$ R. v. Van der Peet, supra note 1 at para. 304

3I $\quad$ bid. at para. 305-306. 
[T] he range of permitted limitation of an established aboriginal right is confined [in Sparrow] to the exercise of the right rather than to the diminution, extinguishment or transfer of the right to others.... The extension of the concept of compelling objective to matters like economic and regional fairness and the interests of nonaboriginal fishers, by contrast, would negate the very aboriginal right to fish itself, on the ground that this is required for the reconciliation of aboriginal rights and other interests and the consequent good of the community as a whole. This is not limitation required for the responsible exercise of the right, but rather limitation on the basis of the economic demands of non-aboriginals. It is a limitation of a different order than the conservation, harm prevention type of limitation sanctioned in Sparrow.

Justice McLachlin also attacked Lamer C.J.'s use of reconciliation as a justification for infringing Aboriginal rights. While recognizing that reconciliation is "a goal of fundamental importance," ${ }^{, 32}$ she pointed out that: ${ }^{33}$

[ $t$ ]he question is how this reconciliation of the different legal cultures of aboriginal and non-aboriginal peoples is to be accomplished. More particularly, does the goal of reconciliation of aboriginal and nonaboriginal interests require that we permit the Crown to require a judicially authorized transfer of the aboriginal right to nonaboriginals without the consent of the aboriginal people, without treaty, and without compensation? I cannot think it does.

Justice McLachlin emphasized that the traditional method for achieving reconciliation between Aboriginal and non-Aboriginal peoples in Canada is through negotiations that lead to treaties. In the case of the Sto:lo Nation, whose rights were at issue in the Van der Peet case, no treaty had ever been signed with them. She remarked that "[u]ntil we have exhausted the traditional means by which aboriginal and nonaboriginal legal perspectives may be reconciled, it seems difficult to assert that it is necessary for the courts to suggest more radical methods of reconciliation

32 Ibid. at para. 310.
33 Ibid. possessing the potential to erode aboriginal rights seriously." ${ }^{34}$

Justice McLachlin also regarded Lamer C.J.'s approach to the justification issue as "indeterminate and ultimately more political than legal. ${ }^{{ }^{3} 35} \mathrm{We}$ will return to this aspect of her critique after examining Lamer C.J.'s approach to the second part of the justification test.

As discussed above, the second part of the test requires proof that the measures taken to meet a legislative objective which has been shown to be valid are consistent with the Crown's fiduciary duty to the Aboriginal peoples. In his majority judgment in Gladstone, Lamer C.J. watered down this branch of the justification test as well. It will be recalled that the Court in Sparrow decided that, where conservation measures are necessary to preserve a resource such as the fishery, the impact of the measures must fall on nonAboriginal users of the resource first. In the context of that case, this meant that the Aboriginal right in question, namely the right to fish for food, social and ceremonial purposes, had to be given top priority because it took precedence over non-Aboriginal commercial and sport fishing. ${ }^{36}$ While purporting to maintain this requirement of priority, Lamer C.J. decided that it could not operate in the same way in the circumstances of the Gladstone case. The distinction he saw was that in Sparrow the right was internally limited by the fact that the Musqueam only needed so much fish for food, social and ceremonial purposes, whereas the right of the Heiltsuk to sell herring spawn commercially in Gladstone was not subject to any internal limitation - the only limitations in that context were external, namely the availability of the resource and the demands of the market. The problem Lamer C.J. found with giving top priority to a right that has no internal limitations was that it would make the right an exclusive one. He put it this way: ${ }^{37}$

Because the right to sell herring spawn on kelp to the commercial market can never be said to be satisfied while the resource is still available and the market is not sated, to give priority to that right in the manner suggested in Sparrow would be to give the right-holder exclusivity over any person not having an

$34 \quad$ Ibid. at para. 313.

$35 \quad$ Ibid. at para. 302.

36 In $R$. v. Adams, supra note 5 at para. 59, the Supreme Court affirmed that the Aboriginal right to fish for food "should be given first priority after conservation concerns are met." See also $R$. v. Coté, supra note 6 at para. 82

$37 \quad R$. v. Gladstone, supra note 3 at para. 59. 
aboriginal right to participate in the herring spawn on kelp fishery.

I fail to understand why this right would be exclusive except in circumstances where the Heiltsuk were capable of taking all the herring spawn on kelp available after conservation requirements had been met. But leaving that aside, the main problem with Lamer C.J.'s approach is that it ignores the Sparrow rationale for giving top priority to Aboriginal fishing rights, namely that those rights are constitutionally protected while the rights of non-Aboriginal users of the resource are not. It is the constitutional status of the Aboriginal right which determines its priority, not the nature of the specific Aboriginal right in question. But Lamer C.J. down-played the significance of this constitutional status by saying that constitutionalization of Aboriginal fishing rights, while resulting in priority for those rights, cannot have been intended to extinguish the right of the public generally to fish.

So what did Lamer C.J. mean. when he said that an Aboriginal right to fish commercially has priority over non-Aboriginal fishing, but not the kind of priority contemplated in Sparrow? It is at this point that the analysis becomes vague. Here is Lamer C.J.'s explanation: ${ }^{38}$

Where the aboriginal right is one that has no internal limitation then the doctrine of priority does not require that, after conservation goals have been met, the government allocate the fishery so that those holding an aboriginal right to exploit that fishery on a commercial basis are given an exclusive right to do so. Instead, the doctrine of priority requires the government to demonstrate that, in allocating the resource, it has taken account of the existence of aboriginal rights and allocated the resource in a manner respectful of the fact that those rights have priority over the exploitation of the fishery by other users. This right is at once both procedural and substantive; at the stage of justification the government must demonstrate both that the process by which it allocated the resource and the actual allocation of the resource which results from that process reflect the prior interest of aboriginal rights holders in the fishery.

$38 \quad$ Ibid. at para. 62.
Chief Justice Lamer admitted that the "content of this priority - something less than exclusivity but which nonetheless gives priority to the aboriginal right must remain somewhat vague pending consideration of the government's actions in specific cases." $39 \mathrm{He}$ analogized with the approach under section 1 of the Charter, "requiring the courts to scrutinize government action for reasonableness on a case-by-case basis." 40 But we have seen that in Sparrow the Court specifically rejected reasonableness as a standard for deciding the validity of a legislative objective because reasonableness was not a sufficient justification for infringing constitutional rights. If the vague standard of reasonableness cannot justify a legislative objective, how can it meet the second part of the justification test which requires the government action to be consistent with the fiduciary duty owed to the aboriginal peoples?

In her dissenting opinion in Van der Peet, McLachlin J. was just as critical of Lamer C.J.'s position on the second part of the justification test as she was of his position on the first part. She began by pointing out that: ${ }^{41}$

[t]he duty of a fiduciary, or trustee, is to protect and conserve the interest of the person whose property is entrusted to him.... The Chief Justice's test, however, would appear to permit the constitutional aboriginal fishing right to be conveyed by regulation, law or executive act to nonnative fishers who have historically fished in the area in the interests of community harmony and reconciliation of aboriginal and non-aboriginal interests.

She also thought that his approach might "render meaningless" the priority scheme set out in Sparrow. ${ }^{42}$ She said this: ${ }^{43}$

On his test, once conservation is satisfied, a variety of other interests, including the historical participation of non-native fishers, may justify a variety of regulations governing distribution of the resource. The only

\footnotetext{
39 Ibid. at para. 63 .

40 Ibid.

4) R. v. Van der Peet, supranote 1 at para. 307.

42 Ibid.

43 Ibid. Note that McLachlin J. avoided Lamer C.J.'s exclusivity concem by limiting the Aboriginal right in question "to supplying what the aboriginal people traditionally took from the fishery" (ibid. at para. 311).
} 
requirement is that the distribution scheme 'take into account' the aboriginal right.

Moreover, in her view Lamer C.J.'s approach inappropriately applies to section $35(1)$ a section 1 Charter analysis, whereby an infringement of an individual right "may be justified if this is in the interest of Canadian society as a whole." 44 While such an analysis is specifically authorized by section 1 , she observed that: ${ }^{45}$

the framers of section 35(1) deliberately chose not to subordinate the exercise of aboriginal rights to the good of society as a whole... To follow the path suggested by the Chief Justice is, with respect, to read judicially the equivalent of section 1 into section $35(1)$, contrary to the intention of the framers of the constitution.

As mentioned above, McLachlin J. also regarded Lamer C.J.'s approach to the justification issue as "indeterminate and ultimately more political than legal." 46 She found evidence of imprecision in the suggestion that, " '[i]n the right circumstances', themselves undefined, governments may abridge aboriginal rights on the basis of an undetermined variety of considerations. ${ }^{, 47}$ She continued ${ }^{48}$

While "account" must be taken of the native interest and the Crown's fiduciary obligation, one is left uncertain as to what degree. At the broadest reach, whatever the government of the day deems necessary in order to reconcile aboriginal and nonaboriginal interests might pass muster. In narrower incarnations, the result will depend on doctrine yet to be determined. Upon challenge in the courts, the focus will predictably be on the social justifiability of the measure rather than the rights guaranteed.

Justice McLachlin's final salvo was levelled at Lamer C.J.'s suggestion that, in her words, "aboriginals may be required to share their fishing rights with nonaboriginals in order to effect a reconciliation of

$44 \quad$ lbid. at para. 308 .

45. Ibid. McLachlin J. was implicitly relying on the fact that s. $35(1)$ is outside the Charter, and therefore is not subject to s.1.

$46 \quad$ Ibid. at para. 302

47 lbid. at para. 309.

4. Ibid. aboriginal and non-aboriginal interests." is unconstitutional. She put it this way: ${ }^{50}$

How, without amending the constitution, can the Crown cut down the aboriginal right? The exercise of the rights guaranteed by section $35(1)$ is subject to reasonable limitation to ensure that they are used responsibly. But the rights themselves can be diminished only through treaty and constitutional amendment. To reallocate the benefit of the right from aboriginals to nonaboriginals would be to diminish the substance of the right that section 35(1) of the Constitution Act, 1982 guarantees to the aboriginal people. This no court can do.

Coming from a colleague, this is incisive criticism of Lamer C.J.'s approach to the justification test. Moreover, it is criticism that went largely unanswered in his judgment in Gladstone, even though Van der Peet was released the same day. In my view, what Lamer C.J. has done on behalf of the majority is virtually to abdicate the Supreme Court's responsibility for upholding what are supposed to be the constitutional rights of the Aboriginal peoples. On his approach, those rights can now be overridden on broad policy grounds relating to economic and regional fairness, and even to support the economic interests of particular groups such as commercial fishers whose historic use of the fishery may well have been a violation of Aboriginal rights all along. The extent to which the Supreme Court will scrutinize government actions to protect Aboriginal rights against infringement remains unclear. One can only hope that in specific situations the Court will hold the federal government to a high fiduciary standard before sanctioning infringements of Aboriginal rights, but the deferential attitude to government policy which I detect in Gladstone is disappointing, to say the least, and does not augur well for the future.

\section{Kent McNeil}

Osgoode Hall Law School, York University. 